\title{
The Skill of Writing
}

\author{
Bryan S. Judge
}

Published online: 9 May 2012

(C) American College of Medical Toxicology 2012

"How can I tell what I think till I see what I say?" E.M. Forster

Aspects of the Novel, 1927

\section{The Skill of Writing}

Recently, I asked some of my medical toxicology colleagues: "What is the most important skill a medical toxicologist can have?" They provided a splendid range of answers: diagnosing and caring for severely ill undifferentiated patients, deductive and inductive reasoning, understanding dose-response relationships, etc. Surprisingly, no one answered "writing skills." While many skills are essential for the successful practice of medical toxicology, I would argue that writing skills supersede all others, especially when the question is framed in light of academics.

In 1975, Michael Crichton described medical writing as awkward, bad, and weak [1]. Almost four decades

This editorial is based on a presentation given on 17 March 2012 at the Fellows-in Training Luncheon-ACMT Spring Conference in San Diego, CA.

\section{B. S. Judge}

Grand Rapids Medical Education Partners/Michigan State

University Emergency Medicine Residency,

Grand Rapids, MI, USA

\section{B. S. Judge}

Department of Emergency Medicine,

Michigan State University College of Human Medicine,

Grand Rapids, MI, USA

\section{B. S. Judge $(\bowtie)$}

Spectrum Health-Toxicology Services,

1900 Wealthy Street SE Suite 255,

Grand Rapids, MI 49506, USA

e-mail: bryan.judge@spectrumhealth.org later, not a lot has changed. Formal instruction in writing or scientific writing is not typically part of residency or fellowship curricula. In fact, I am unaware of a single Medical Toxicology Fellowship program that currently offers formal instruction in writing, scientific writing, or peer review on a consistent basis. Polished writing skills remain vital to fulfilling our scientific mission of advancing the field and igniting ideas for further study. Why then do residency and fellowship programs place little - if anyemphasis on this important aspect of graduate medical education?

Let's face it - writing is often viewed to be an unpleasant task. For many of us, it is something that does not come easy. Teaching someone to be a better writer is even more challenging. To top things off, budding and seasoned authors alike get frustrated when their stylistic expression is quashed to meet the dull and formulaic format of many medical journals [2]. Other barriers to writing have been identified and include lack of time, no confidence, anxiety, and the inability to start or finish [3]. Although the roadblocks to effective writing seem insurmountable at times, the real challenge before us is imparting the importance and power of written communication to our legacy of learners - to spark a flame where perhaps there was none before.

\section{The Impact of Writing}

The question posed above by E.M. Forster embodies the spirit of the write to learn pedagogical philosophy. Writing can and should be used to help us unearth what we know or think about myriad topics. The learning yield from writing in detail about a specific subject is exponential. These tenets hold true whether or not what you write is ever destined for publication. 
The impact of good writing can be great. A well-written case report, study, or review can present data and a degree of analysis that is too difficult to communicate orally. The ability to write well can secure a grant, disperse a cogent idea, facilitate academic promotion, or influence a global audience. Poor writing skills can lose each of these, as well as respect for the writer.

Brevity, clarity, conviction, and passion are the keys to writing well. The power of ideas is enhanced through the clarity of writing. Case in point - Crick and Watson's eloquent yet concise description for the structure of DNA published in 1953 [4]. Clear. Groundbreaking. Powerful. Accomplished with just one page.

Before you even peck that keyboard, promise yourself that you will write with conviction and passion. Articles that lack them make others nod off. Where is the power in that? Power is not how many times your article has been cited. But if you have reached a single reader-whether a medical student, resident, fellow, or seasoned attending physicianwith your message, then your mission is a success. Behold the power of that.

\section{Moving Forward}

It is time that we teach our learners, each other, and ourselves to become better writers. Change is necessary on multiple levels to help us unleash the writer that resides within. That transformation begins with each of you reading this.

To start, here are a few tips to enhance your writing skills:

- Write on a consistent basis. Set aside some blocks of time each week to write.

- Make sure your writing time is free of interruptions and when you are most productive.

- Parcel the paper into parts and tackle the easy stuff first.

- Write like you are telling a story.

- Take time to read good writing. Examples can be found routinely in National Geographic, Nature, The New Yorker, and The Wall Street Journal.

- Never be completely satisfied with your work-revise multiple times and wordsmith with each revision.

- Find a mentor who is well versed in the skill of writing.

- The path to effective writing is long and tortuous. Be sure to enjoy the journey along the way.

The next step is to incorporate formal instruction on writing and scientific writing into the curricula of our fellowship training programs. When you dissect the Core Content of Medical Toxicology, its main thrust is knowledge acquisition [5]. Instead, the Core Content should be revamped to focus not only on the knowledge necessary to practice medical toxicology but also provide conceptual frameworks and practices on how to best develop the skills and attributes of learners that will enhance care in the future and move our field forward.

Developing a writing curriculum does not have to be an onerous task. A robust curriculum can be designed with Kern's six-step approach to curriculum development [6]. Several articles [7-9] and texts [10-12] on improving writing and scientific writing can be utilized in designing educational strategies to enhance these skills.

Finally, the American College of Medical Toxicology should hold writing workshops at its national meetings. Yeah, I know what you are thinking... "sounds like a setup for a big yawn session." On the contrary, these workshops should serve as a catalyst to get others excited about writing and a platform to exchange ideas on how we can polish our writing skills, teach others to become better writers, and publish like a pro.

There need not be mystery to the skill of writing and doing it well. It is not up to the writing gods to help put pen to paper. Rather, it is up to us as educators and responsible learners to develop, maintain, and hone the important and powerful skill of writing.

Conflict of Interest The author has no conflicts, financial, or otherwise to disclose.

\section{References}

1. Crichton M (1975) Sounding board: medical obfuscation: structure and function. N Engl J Med 293(24):1257

2. Franzblau LE, Kotsis SV, Chung KC (2012) Scientific writing for enjoyable reading: how to incorporate style into scientific manuscripts. Plast Reconstr Surg 129(2):543

3. Boice R (1990) Professors as writers: a self-help guide to productive writing. New Forums Press Inc., Stillwater, OK, p 186

4. Watson JD, Crick FHC (1953) Molecular structure of nucleic acids: a structure for deoxyribose nucleic acid. Nature 171 (4356): 737

5. Wax PM, Ford MD, Bond GR et al (2004) The core content of medical toxicology. Ann Emerg Med 43(2):1

6. Kern DE, Thomas PA, Hughes MT (eds) (2009) Curriculum development for medical education: a six-step approach, 2nd edn. The Johns Hopkins University Press, Baltimore, p 272

7. Flatt AE (2000) Words. J Hand Surg 25(2):201

8. Guilford WH (2001) Teaching peer review and the process of scientific writing. Adv Physiol Educ 25(3):167

9. Ludbrook J (2007) Writing intelligible English prose for biomedical journals. Clin Exp Pharmacol Physiol 34:508

10. Strunk W Jr, White EB (1999) The elements of style, 4th edn. Longman, New York, p 105

11. King S (2010) On writing: a memoir of the craft. Scribner, New York, $\mathrm{p} 288$

12. Zinssner W (2006) On writing well. Harper Perennial, New York, p 336 